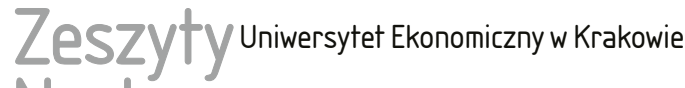 Naukowe
}

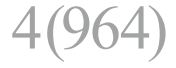

ISSN 1898-6447

Zesz. Nauk. UEK, 2017: 4(964): 81-98 DOI: 10.15678/ZNUEK.2017.0964.0405

Agnieszka Sitko-Lutek

Monika Jakubiak

\section{Style uczenia się i umiejętności pracowników w kontekście wybranych segmentów rynku pracy $^{*}$}

\section{Streszczenie}

Problematyka opracowania dotyczy stylów uczenia się i umiejętności pracowników współczesnych innowacyjnych przedsiębiorstw rozpatrywanych w kontekście wybranych segmentów rynku pracy. Współczesny rynek pracy może być analizowany na podstawie wielu kryteriów, w tym przypadku skoncentrowano się jednak na podziale ze względu na stanowiska zajmowane w organizacjach. Celem badań było sprawdzenie, czy stanowiska zajmowane przez respondentów wpływają na prezentowane przez nich style uczenia się i posiadane umiejętności. Wyniki badań w tym zakresie mogą zostać wykorzystane przez menedżerów i specjalistów zatrudnionych w działach HR do projektowania systemów zarządzania zasobami ludzkimi dostosowanych do potrzeb pracowników reprezentujących poszczególne grupy stanowisk.

Agnieszka Sitko-Lutek, Uniwersytet Marii Curie-Skłodowskiej w Lublinie, Wydział Ekonomiczny, Zakład Zarządzania, pl. M. Curie-Skłodowskiej 5, 20-031 Lublin, e-mail: agnieszka. sitko-lutek@poczta.umcs.lublin.pl

Monika Jakubiak, Uniwersytet Marii Curie-Skłodowskiej w Lublinie, Wydział Ekonomiczny, Zakład Zarządzania, pl. M. Curie-Skłodowskiej 5, 20-031 Lublin, e-mail: monika.jakubiak@ poczta.umcs.lublin.pl

* Badania zrealizowano w ramach projektu pn. „Potencjał kompetencyjny wybranych grup pracowników w aspekcie zarządzania różnorodnością w innowacyjnych przedsiębiorstwach" (umowa nr UMO-2013/09/B/HS4/01307). 
Badania empiryczne przeprowadzono metodą sondażu diagnostycznego wykorzystującego technikę ankiety wśród 1365 pracowników innowacyjnych przedsiębiorstw z siedzibą na terenie Polski. Uzyskane dane poddano analizie statystycznej. Wnioski z badań pozwoliły na sformułowanie rekomendacji dla menedżerów i specjalistów HR dotyczących zarządzania zespołami pracowników współczesnych przedsiębiorstw.

Słowa kluczowe: style uczenia się, umiejętności pracowników, segmenty rynku pracy, kompetencje.

Klasyfikacja JEL: A20, J24, M54.

\section{Wprowadzenie}

W czasach gospodarki opartej na wiedzy (GOW) źródłem trwałej przewagi konkurencyjnej coraz częściej stają się zasoby niematerialne, takie jak kompetencje, reputacja, działania innowacyjne i kreatywność. Tematyka prezentowanego opracowania dotyczy stylów uczenia się oraz umiejętności pracowników współczesnych innowacyjnych przedsiębiorstw, rozpatrywanych w kontekście wybranych segmentów rynku pracy.

W literaturze przedmiotu podkreśla się znaczenie stylu poznawczego pracowników i posiadanych przez nich umiejętności dla skutecznego zarządzania organizacją i osiągania wymiernych efektów. Niezwykle istotna jest także rola menedżerów, ich kompetencje i umiejętności oraz podejście do rozwoju własnego i podwładnych. Wiedza i umiejętności kierowników są bowiem następnie przekazywane na niższe szczeble organizacji, to oni są odpowiedzialni za kulturę organizacyjną, inicjowane zachowania oraz zmiany w organizacjach.

Celem prezentowanego artykułu jest identyfikacja i ocena wzajemnych zależności pomiędzy stylem uczenia się i umiejętnościami a profilem zajmowanego stanowiska oraz odpowiedź na pytanie, czy rodzaj podejmowanych zadań ma wpływ na prezentowane style uczenia się oraz na deklarowane umiejętności.

\section{Kompetencje i umiejętności pracowników w świetle literatury przedmiotu}

Tematyka artykułu wpisuje się w dyskurs na temat umiejętności. Definicję tego pojęcia warto jednak poprzedzić przybliżeniem problematyki kompetencji pracowniczych, będących pojęciem szerszym niż umiejętności [Oleksyn 2006, Rakowska 2007].

W literaturze przedmiotu dominują dwa podejścia do analizy i opisu kompetencji w organizacji. W szerszej perspektywie podkreśla się wpływ kompetencji organizacji na budowanie przewagi konkurencyjnej przedsiębiorstwa na rynku. 
Kompetencje organizacji składają się z unikalnej i specyficznej wiedzy oraz z doświadczeń i umiejętności organizacji, które zostały w niej wykształcone. Zwolennicy podejścia badawczego, zwanego perspektywą kompetencyjną (competence based perspective), skupiają się przede wszystkim na analizie wnętrza organizacji, starając się tam właśnie znaleźć źródła przewagi konkurencyjnej. Upatrują oni możliwości uzyskania i utrzymania przewagi nad konkurentami w niepowtarzalnej kompozycji zasobów oraz zdolności umożliwiających organizacji uzyskiwanie regularnych dochodów dzięki posiadanym kompetencjom [Wernerfelt 1984].

Drugie podejście proponuje postrzeganie kompetencji organizacyjnych w kontekście kompetencji pracowników. Kompetencje indywidualne poszczególnych członków składają się na potencjał pracy całej organizacji. Indywidualny potencjał pracy każdego pracownika tworzą jego wiedza i umiejętności zawodowe (zwane także kompetencjami twardymi) oraz predyspozycje, cechy osobowości, motywacja, a nawet role społeczne (kompetencje miękkie) [Leksykon zarzqdzania... 2006]. Potencjał kompetencyjny organizacji stanowi tym samym iloczyn indywidualnych potencjałów pracy wyrażony liczbą osób zatrudnionych w firmie oraz indywidualnego czasu pracy [Polskie firmy... 2007].

Problematyka niniejszego opracowania dotyczy umiejętności pracowników przedsiębiorstw analizowanych do tej pory przez wielu badaczy przedmiotu. Zazwyczaj podkreślają oni, że nabycie pewnych umiejętności nie gwarantuje posiadania kompetencji [Boyatzis 1982, Prien 1977, Argyle 1967]. Aby pracownik był kompetentny, powinien bowiem posiadać wiele cech umożliwiających mu przełożenie posiadanych umiejętności na skuteczne działanie [Antonacopoulou i Fitzgerald 1996]. W literaturze toczy się ponadto dyskusja na temat różnic pomiędzy kompetencjami a umiejętnościami. T. Oleksyn uważa, że kompetencje pracownicze są pojęciem szerszym i obejmującym obok umiejętności także wiedzę i wykształcenie, doświadczenie, postawy i zachowania, uzdolnienia, predyspozycje, motywację oraz cechy psychofizyczne [Oleksyn 2006]. Z kolei P. Juceviciene i D. Lepaitte wprowadzili holistyczny model kompetencji, uznając, że kompetencje uwarunkowane są indywidualną wiedzą i umiejętnościami, jak również motywami, cechami osobistymi oraz wartościami [Juceviciene i Lepaitte 2004]. Podobnego zdania jest A. Rakowska, według której umiejętności związane są z zachowaniami jednostki jako reakcjami na płynące $\mathrm{z}$ otoczenia bodźce i kształtują posiadane przez daną osobę kompetencje [Rakowska i Sitko-Lutek 2000].

W literaturze podkreśla się rosnące znaczenie umiejętności pracowników, w tym w szczególności liderów i menedżerów organizacji. Umiejętności menedżerów w znacznym stopniu determinują bowiem możliwości rozwoju, co jest ważne zarówno dla zatrudniających ich organizacji, jak również dla funkcjonowania samych pracowników na zmieniającym się rynku pracy. Kapitał złożony z pracow- 
ników, ich wiedzy i umiejętności nie ma jednak stałego charakteru. Obecnie, jak nigdy wcześniej, kompetencje ulegają dewaluacji, starzeją się, wymagają więc inwestycji w doskonalenie [Łaguna i in. 2015]. Organizacje, które zauważają te potrzeby, stawiają na rozwój pracowników. Jest to niewątpliwie kosztowne, ale inwestycja w rozwój potencjału pracowników może przynieść nieporównywalnie większe korzyści, takie jak wzrost zaangażowania w wykonywane zadania, zadowolenia z pracy, dobrostan ${ }^{1}$ itp. [Filipowicz 2014]. Jak wynika z prezentowanych w literaturze badań przeprowadzonych wśród pracowników przedsiębiorstw, ich dobrostan zależy w dużej mierze od poziomu kontroli nad życiem oraz zgodności wartości celów i działań. Nie zawsze jednak wysoki poziom dobrostanu skutkuje równie wysokim zaangażowaniem w wykonywane zadania. W celu zapewnienia wysoko wykwalifikowanej, kompetentnej, lojalnej kadry należy więc troszczyć się o pracowników i ich stały rozwój [Bartkowiak 2011].

W ostatnich latach w nurcie odpowiedzialności społecznej biznesu (corporate social responsibility - CSR) na znaczeniu zyskuje także dbałość o równowagę pomiędzy życiem zawodowym a prywatnym (work-life balance - W-LB), która może być rozpatrywana na poziomie zarówno jednostki (pracownika), jak też całej organizacji. Zwolennicy tej koncepcji podkreślają potrzebę kreowania takich sposobów pracy i warunków jej wykonywania, które odpowiadają potrzebom pracowników oraz klientów [Borkowska 2010].

\section{Style poznawcze w dotychczasowych badaniach}

Oprócz umiejętności menedżerów oraz zatrudnionych pracowników dla rozwoju potencjału kompetencyjnego istotne są style uczenia się (w literaturze określane także jako style poznawcze). Determinują one sposób myślenia, identyfikacji faktów, zapamiętywania informacji. Podejmując rozważania na temat stylów poznawczych, warto przybliżyć pojęcie uczenia się, szeroko omawiane w literaturze i rożnie interpretowane przez badaczy przedmiotu. Część opracowań przedstawia uczenie się jako sytuację lub czynność nabywania wiedzy lub umiejętności. Uczenie się jest jednak także interpretowane jako proces, w którym zdobywane przez jednostkę doświadczenia zostają utrwalone, w konsekwencji prowadząc do zmian w jej zachowaniu [Mietzel 2003]. Szeroko omawianym pojęciem jest także styl poznawczy. Zdaniem A. Matczaka jest to „preferowany sposób funkcjonowania poznawczego, odpowiadający indywidualnym potrzebom jednostki" [2004, s. 761]. Nieco inaczej interpretują to pojęcie R. Riding i S. Rayner, zdaniem których styl poznawczy oznacza „wbudowany i automa-

${ }^{1}$ Dobrostan pracowników obejmuje przystosowanie, dobry poziom zdrowia psychicznego oraz niski poziom wypalenia. 
tyczny sposób odpowiadania na informacje i sytuacje”, jak również „preferowane przez jednostkę podejście do organizowania informacji i tworzenia ich reprezentacji” [Riding i Rayner 1998, s. 7-8].

W prezentowanym opracowaniu wykorzystano interpretację i metodykę przyjętą przez Ch. Allinsona i J. Hayesa [2012], zdaniem których styl poznawczy decyduje przede wszystkim o sposobie gromadzenia, przetwarzania oraz oceny danych. Stanowi on tym samym podstawową determinantę sposobu poszukiwania informacji w środowisku, jak również ich organizowania, interpretacji i integrowania w modele umysłowe i teorie kierujące następnie zachowaniem jednostki. Autorzy podkreślają znaczenie, jakie ma znajomość stylu poznawczego poszczególnych osób dla praktyki biznesowej. Wiedza o stylu poznawczym może być ich zdaniem szczególnie przydatna w przypadku selekcji kandydatów do pracy, planowania ścieżki kariery, budowania zespołów zadaniowych, zarządzania konfliktem oraz w mentoringu, szkoleniach i szeroko pojętym rozwoju [Allinson i Hayes 2012].

Ch. Allinson i J. Hayes zaproponowali metodykę badania stylów poznawczych z uwzględnieniem wymiaru analitycznego-intuicyjnego, ich zdaniem stanowiącego odbicie różnic w sposobie podejścia przez jednostkę do rozwiązywania problemów oraz podejmowania decyzji [Riding i Rayner 1998]. Jednocześnie zdaniem badaczy tylko niewielką część osób można byłoby sklasyfikować jako w pełni analityczne lub intuicyjne. Zaproponowany przez nich wymiar stanowi bowiem pewne kontinuum, na którym można odnaleźć jednostki o różnym nasileniu danej cechy. Na podstawie wyników badań zrealizowanych z wykorzystaniem autorskiego kwestionariusza stylów poznawczych Ch. Allinson i J. Hayes wyróżnili pięć stylów poznawczych: analityczny, quasi-analityczny, adaptacyjny, quasi-intuicyjny oraz intuicyjny. Styl analityczny cechuje się dużą logiką w podejmowaniu działań i umiejętnością koncentracji na szczegółach, z kolei styl intuicyjny zakłada dokonywanie syntez i całościową ocenę sytuacji [Allinson i Hayes 2012].

\section{Współczesny rynek pracy - tendencje i determinanty zmian}

W niniejszym artykule style poznawcze oraz umiejętności analizowane są w kontekście wybranych segmentów runku pracy. Należy podkreślić, że obecnie wszystkie obszary krajowych gospodarek na całym świecie podlegają tendencjom międzynarodowym. Jest to szczególnie widoczne w przypadku rynków pracy zmieniających się zarówno pod wpływem czynników pochodzących z poszczególnych krajów, jak też determinant zewnętrznych powstających w przestrzeni międzynarodowej. Wśród najistotniejszych trendów międzynarodowych E. Kryńska [2007] wymienia globalizację, postęp techniczny i technologiczny oraz zmiany treści pracy. 
Jak podkreślają badacze, rynek pracy jest pojęciem złożonym i niejednorodnym, składają się bowiem na niego indywidualne rynki pracy, dotyczące konkretnych grup z uwzględnieniem kwalifikacji, doświadczeń i umiejętności danych osób. Rynek pracy jest więc rodzajem rynku ujmowanym w kontekście relacji między podażą a popytem, gdzie przedmiot transakcji zakupu i sprzedaży stanowi praca. Współczesny rynek pracy nie jest rynkiem homogenicznym - składa się z wewnętrznych rynków cząstkowych posiadających własne mechanizmy regulacji. Jest to tzw. segmentacja rynku pracy, tj. podział na wyodrębnione części, tzw. subrynki lub segmenty. Segmenty rynku pracy obejmują zbliżone jakościowo miejsca pracy, jak również pracobiorców o zbliżonych kwalifikacjach oraz podobnych cechach [Kryńska 2003]. Poszczególne segmenty rynku pracy odróżniają od siebie m.in. zasady wynagradzania i awansowania, zasady dostępu, stopień instytucjonalizacji stosunków zatrudnienia. Współczesny rynek pracy oraz jego poszczególne segmenty mogą więc być analizowane $\mathrm{z}$ uwzględnieniem wielu kryteriów. W prezentowanym opracowaniu skoncentrowano się na podziale ze względu na stanowiska pracy oraz zadania realizowane przez pracowników badanych organizacji.

Niebagatelne konsekwencje zarówno dla współczesnego rynku pracy, jak i dla jego poszczególnych uczestników mają zachodzące w ostatnich latach zmiany w postrzeganiu i przebiegu kariery zawodowej (rozumianej jako zbiór ról zawodowych lub stanowisk pracy danej osoby w czasie całego życia zawodowego) [Sikorski 2008]. Przez wiele lat modelowa kariera zawodowa postrzegana była jako stopniowe awansowanie, dające coraz wyższe stanowiska i wynagrodzenie. Wynikało to m.in. z krótszego niż aktualnie przeciętnego wieku aktywności zawodowej ludzi oraz dłuższego cyklu życia przedsiębiorstw. Obecnie ścieżka kariery zawodowej częściej przypomina kształtem sinusoidę niż wznoszącą się prostą. Ze względu na prowadzenie działalności w dynamicznie zmieniających się warunkach, nasilającą się konkurencję oraz zmiany wewnętrzne współczesne organizacje coraz rzadziej są w stanie zapewnić stały przebieg kariery zawodowej i zatrudnienia swoim pracownikom. W rezultacie kariery wielu osób charakteryzują się dzisiaj nieznaną dotąd dynamiką oraz nieciągłością doświadczeń zawodowych, stają się więc coraz mniej przewidywalne. To z kolei powoduje, że decyzje co do zatrudnienia muszą być podejmowane nie tylko na początku życia zawodowego, ale przez cały okres jego trwania. Ze względu na możliwości rozwoju kariery w wielu różnych organizacjach to jednostki stają się ostatecznie odpowiedzialne za swoje kariery [Verbruggen 2010].

Badacze zajmujący się nowym modelem kariery zawodowej podkreślają, że pracownicy nie mogą już przekazywać organizacji odpowiedzialności za zarządzanie swoimi karierami. Osoby, które chcą realizować się zawodowo w globalnym i stale zmieniającym się świecie pracy, muszą przejąć odpowiedzialność za zarządzanie swoją karierą [Briscoe i Hall 2006]. 
Jednocześnie obserwowane współcześnie szybkie starzenie się wiedzy profesjonalnej skutkuje zjawiskiem krótkotrwałych karier. Kompetencje zawodowe są na tyle nowe, że znajdowane są często wśród młodych ludzi. Wiedza jednak szybko się starzeje lub powszednieje na tyle, że staje się dostępna łatwiej i taniej. W rezultacie młodzi specjaliści, rozpoczynający i błyskawicznie realizujący spektakularne kariery zawodowe, równie szybko zostają zastąpieni przez innych i ich kariera przedwcześnie się kończy. Ponadto istnieje niebezpieczeństwo wypalenia zawodowego; dotyka ono w szczególności młodych, dobrze opłacanych specjalistów [Pissarides 2012].

Determinanty pozycji jednostki na współczesnym rynku pracy można podzielić na indywidualne (zależne od danej osoby lub grupy osób) oraz uzależnione od czynników, na które jednostka nie ma wpływu. Do czynników indywidualnych należą w szczególności wykorzystanie potencjału edukacyjnego, jakość kształcenia i dokształcania oraz struktura aktywności zawodowej. Należą do nich także wiedza i umiejętności pracowników, zarówno twarde, związane z wykonywanym zawodem, jak również miękkie, związane z predyspozycjami do pracy zespołowej. Te ostatnie cieszą się szczególnym zainteresowaniem pracodawców. W świetle wyników prowadzonych dotychczas badań do deficytowych cech kandydatów do pracy zalicza się bowiem nie tylko umiejętności praktyczne (zastosowanie w praktyce zdobytej wiedzy), ale także predyspozycje osobowościowe, takie jak uczciwość, odpowiedzialność czy zaangażowanie [Sztanderska i Wojciechowski 2008].

\section{Metodyka badań własnych}

Badania empiryczne przeprowadzono metodą sondażu diagnostycznego wykorzystującego technikę ankiety w 2015 r. wśród 1365 pracowników innowacyjnych przedsiębiorstw funkcjonujących na terenie Polski.

Kwestionariusz ankiety składał się z dwóch głównych części merytorycznych oraz metryczki. Pierwsza część kwestionariusza dotyczyła prezentowanych przez respondentów umiejętności. Doboru umiejętności do kwestionariusza dokonano na podstawie literatury przedmiotu [Shavelson 2010]. Istotne były dwa obszary: specyfika zadań realizowanych przez badanych w organizacjach oraz możliwość doskonalenia kompetencji w przyszłości. Do oceny wybrano 14 obszarów kompetencyjnych:

1) organizacja czasu pracy własnej,

2) radzenie sobie ze stresem,

3) umiejętność uczenia się,

4) kierowanie własną karierą,

5) komunikacja interpersonalna, 
6) rozwiązywanie konfliktów,

7) współpraca z przedstawicielami innych kultur,

8) przewodzenie, wywieranie wpływu,

9) współpraca z ludźmi w każdym wieku,

10) współpraca z przedstawicielami innej płci,

11) szybkie adaptowanie się do nowych warunków,

12) mobilizowanie się do długotrwałej pracy,

13) wykonywanie oprócz własnych zadań także zadań realizowanych przez innych,

14) kreatywne myślenie.

Respondenci proszeni byli o wskazanie swoich mocnych stron (maksymalnie pięć).

Tabela 1. Struktura respondentów $(n=1365)$

\begin{tabular}{|l|c|}
\hline \multicolumn{1}{|c|}{ Wyszczególnienie } & Procent respondentów \\
\hline Płeć & 51,6 \\
\hline kobieta & 48,4 \\
\hline mężczyzna & \\
\hline Przedział wiekowy & 22,0 \\
\hline 20-29 lat & 34,1 \\
\hline 30-39 lat & 20,5 \\
\hline 40-49 lat & 13,3 \\
\hline 50-59 lat & 3,5 \\
\hline 60-69 lat & 6,5 \\
\hline brak danych & \\
\hline Zajmowane stanowisko & 22,7 \\
\hline wykonawcze & 53,0 \\
\hline specjalistyczne & 15,9 \\
\hline kierownicze & 8,4 \\
\hline brak danych & \\
\hline
\end{tabular}

Źródło: opracowanie własne na podstawie przeprowadzonych badań ankietowych.

Druga merytoryczna część kwestionariusza badawczego dotyczyła stylów uczenia się prezentowanych przez respondentów. Wykorzystano w tym celu metodykę cognitive style index (CSI) zaproponowaną przez Ch. Allinsona i J. Hayesa [2012]. W modelu zidentyfikowano pięć stylów uczenia się:
1) intuicyjny,
2) quasi-intuicyjny,
3) adaptacyjny, 
4) quasi-analityczny,

5) analityczny.

Zebrany materiał empiryczny przedstawiono w postaci tabel krzyżowych, które poddano następnie analizie statystycznej. Ze względu na charakter analizowanych zmiennych wykorzystano test niezależności chi-kwadrat. Jako istotne przyjęto zależności na poziomie $p<0,05$.

W tabeli 1 przedstawiono strukturę respondentów. Zauważono, że w grupie respondentów w niewielkim stopniu przeważały kobiety $(51,6 \%)$. Dominowały osoby w wielu do 49 lat (77\%), co trzeci respondent był w wieku 30-39 lat. Najmniej liczną grupę wiekową stanowiły osoby powyżej 60 roku życia. Ponad połowa badanych zajmowała stanowiska specjalistyczne (53\%), zaś co siódmy pracował jako menedżer.

\section{Umiejętności i style poznawcze a profil stanowiska pracy}

Poszukując odpowiedzi na postawione pytania badawcze, poproszono badanych o wskazanie dominującego profilu zajmowanego stanowiska przez wybór jednej z sześciu zaproponowanych grup zadań. Odpowiedzi respondentów w tym zakresie przedstawia rys. 1 .

Co trzeci badany $(31,8 \%)$ zajmował się w swojej pracy przede wszystkim zadaniami i pracami technicznymi, co czwarty pracami ogólnoadministracyjnymi, organizacyjnymi, prawnymi i kadrowymi. Mniej liczne grupy badanych zajmowały się finansami i sprawozdawczością (17,6\%) lub marketingiem, sprzedażą lub logistyką $(14,6 \%)$. Najmniej osób spośród badanych $(7,4 \%)$ realizowało prace badawcze, projektowe $\mathrm{i}$ innowacyjne.

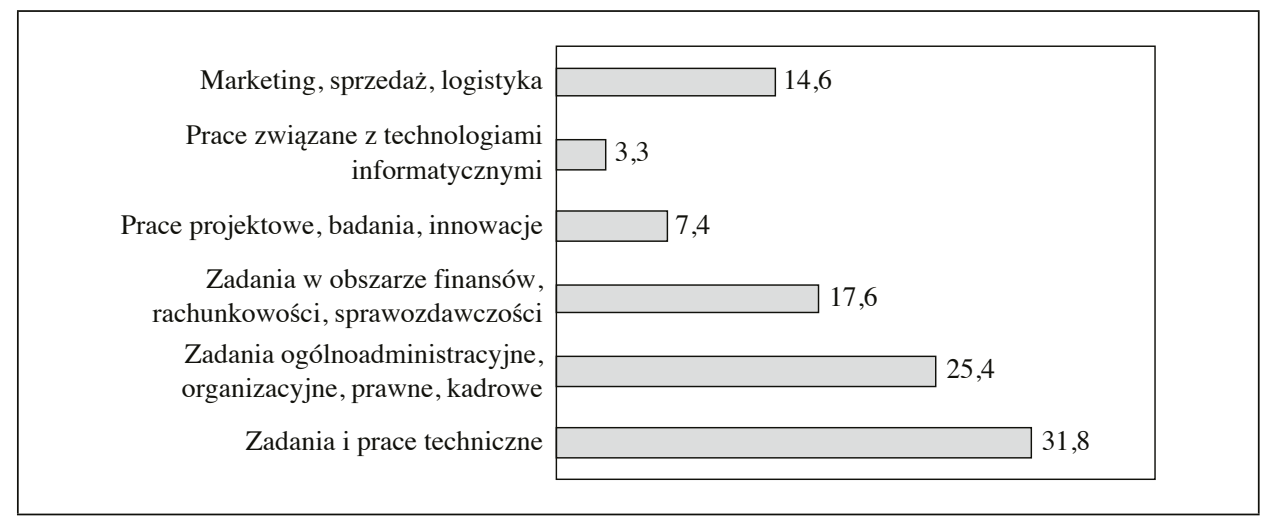

Rys. 1. Dominujący profil stanowiska zajmowanego przez respondentów (w \%) Źródło: opracowanie własne na podstawie przeprowadzonych badań ankietowych. 
Pierwsza część kwestionariusza ankiety dotyczyła samooceny umiejętności respondentów. Poproszono ich o wybór tych obszarów kompetencyjnych, które uważają za swoje mocne strony (można było wskazać maksymalnie pięć). Na rys. 2 przedstawiono odpowiedzi respondentów na to pytanie. $60 \%$ badanych za swoją mocną stronę uznało umiejętność organizacji czasu pracy własnej. Umiejętność uczenia się wskazało 42,2\% respondentów, a współpracę z ludźmi w każdym wieku 39,9\% respondentów.

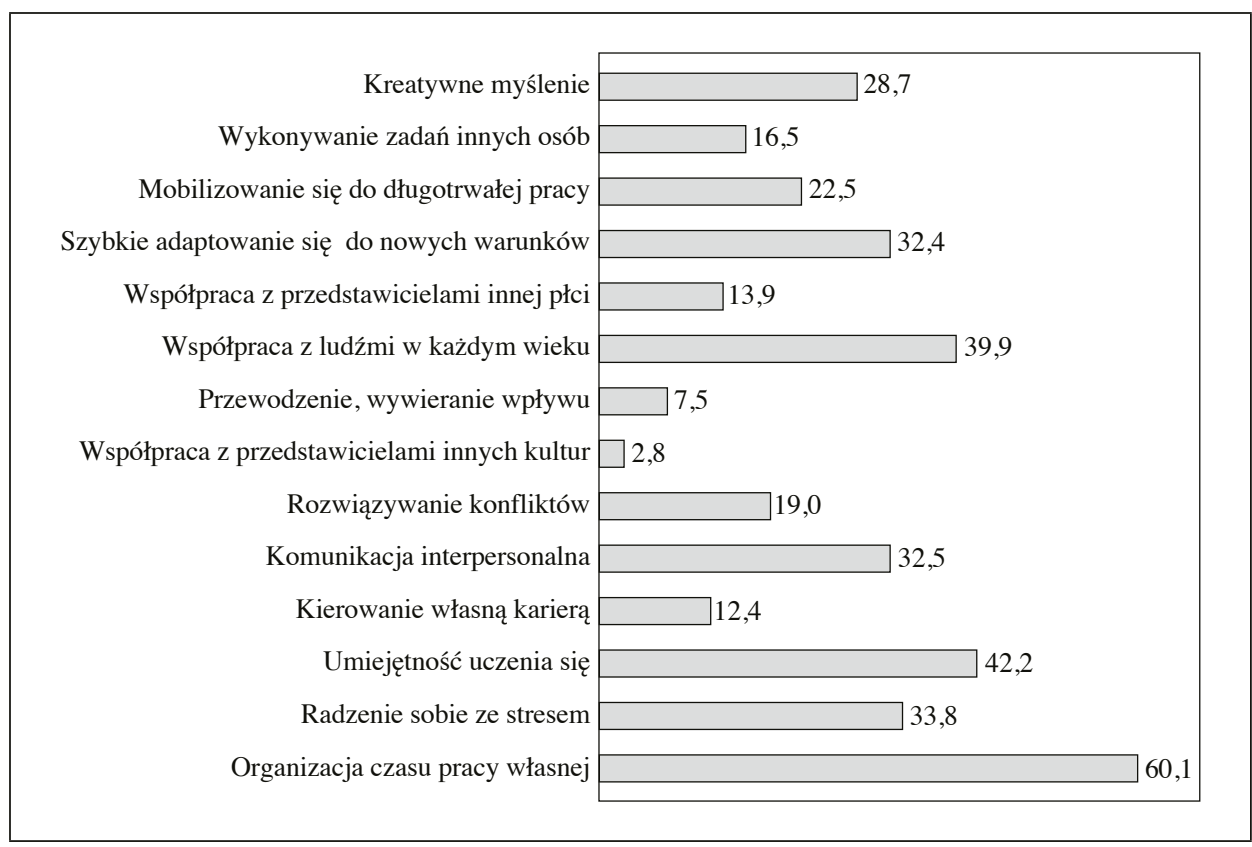

Rys. 2. Posiadane umiejętności w deklaracjach badanych (w \%)

Źródło: opracowanie własne na podstawie przeprowadzonych badań ankietowych.

Co trzeci spośród badanych deklarował umiejętność radzenia sobie ze stresem, komunikacji interpersonalnej lub szybkiego adaptowania się do nowych warunków. Nieco rzadziej wskazywana była umiejętność kreatywnego myślenia $(28,7 \%)$. Najmniej wskazań otrzymała współpraca z przedstawicielami innych kultur, którą za swój atut uznało niespełna 3\% respondentów.

Aby ocenić wpływ dominującego profilu stanowiska pracy na samoocenę umiejętności, analizie poddano zależności między wykonywanymi zadaniami a mocnymi stronami wskazywanymi przez badanych. Istotne statystycznie zależności przedstawiono w tabeli 2. 


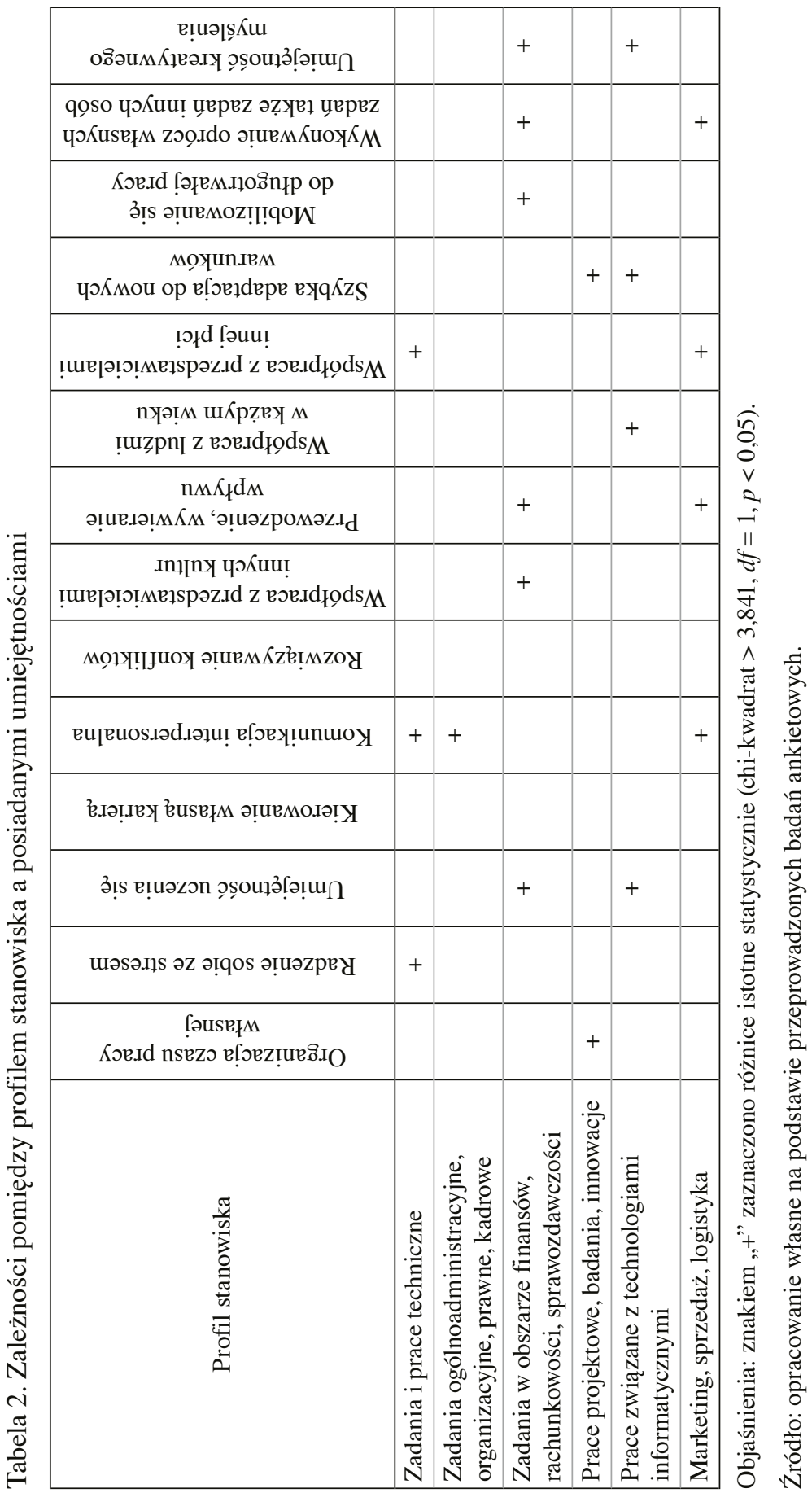


Analiza wyników badań w tym obszarze wykazała, że osoby zajmujące się zadaniami i pracami technicznymi częściej niż pozostali respondenci posiadają umiejętności, takie jak:

- radzenie sobie ze stresem,

- komunikacja interpersonalna,

- współpraca z przedstawicielami innej płci.

Respondenci realizujący zadania administracyjne, organizacyjne, prawne lub kadrowe częściej niż pozostali badani posiadają umiejętności komunikacji interpersonalnej.

Z kolei osoby zajmujące się finansami, rachunkowością oraz sprawozdawczością wyróżniały się na tle innych osób umiejętnościami:

- uczenia się,

- współpracy z przedstawicielami innych kultur,

- przewodzenia, wywierania wpływu,

- mobilizowania się do długotrwałej pracy,

- wykonywania oprócz własnych zadań także zadań innych osób,

- kreatywnego myślenia.

Respondenci, którzy realizują prace projektowe w obszarze badań lub innowacji, częściej niż pozostali charakteryzowali się umiejętnością organizacji czasu pracy własnej oraz szybkiej adaptacji do nowych warunków. Respondenci zajmujący się technologiami informatycznymi częściej niż inni wskazywali umiejętności uczenia się, współpracy z ludźmi w każdym wieku, szybkiej adaptacji do nowych warunków oraz kreatywnego myślenia.

Z kolei osoby wykonujące prace związane z marketingiem, sprzedażą lub logistyką wyróżniały na tle grupy umiejętności komunikacji interpersonalnej, przewodzenia, wywierania wpływu, współpracy z przedstawicielami innej płci oraz wykonywania oprócz własnych zadań także zadań innych osób.

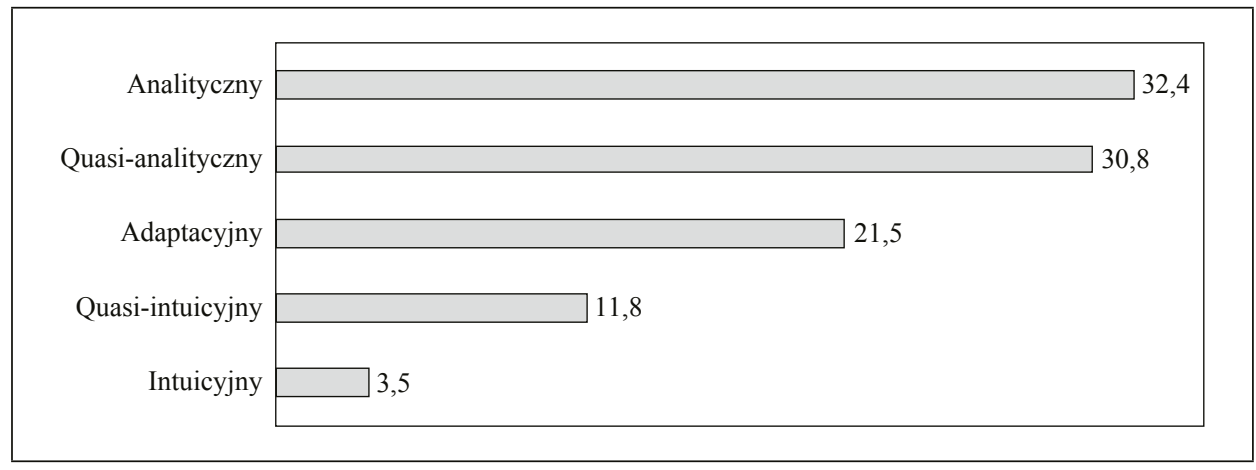

Rys. 3. Style uczenia się prezentowane przez badanych (w \%)

Źródło: opracowanie własne na podstawie przeprowadzonych badań ankietowych. 


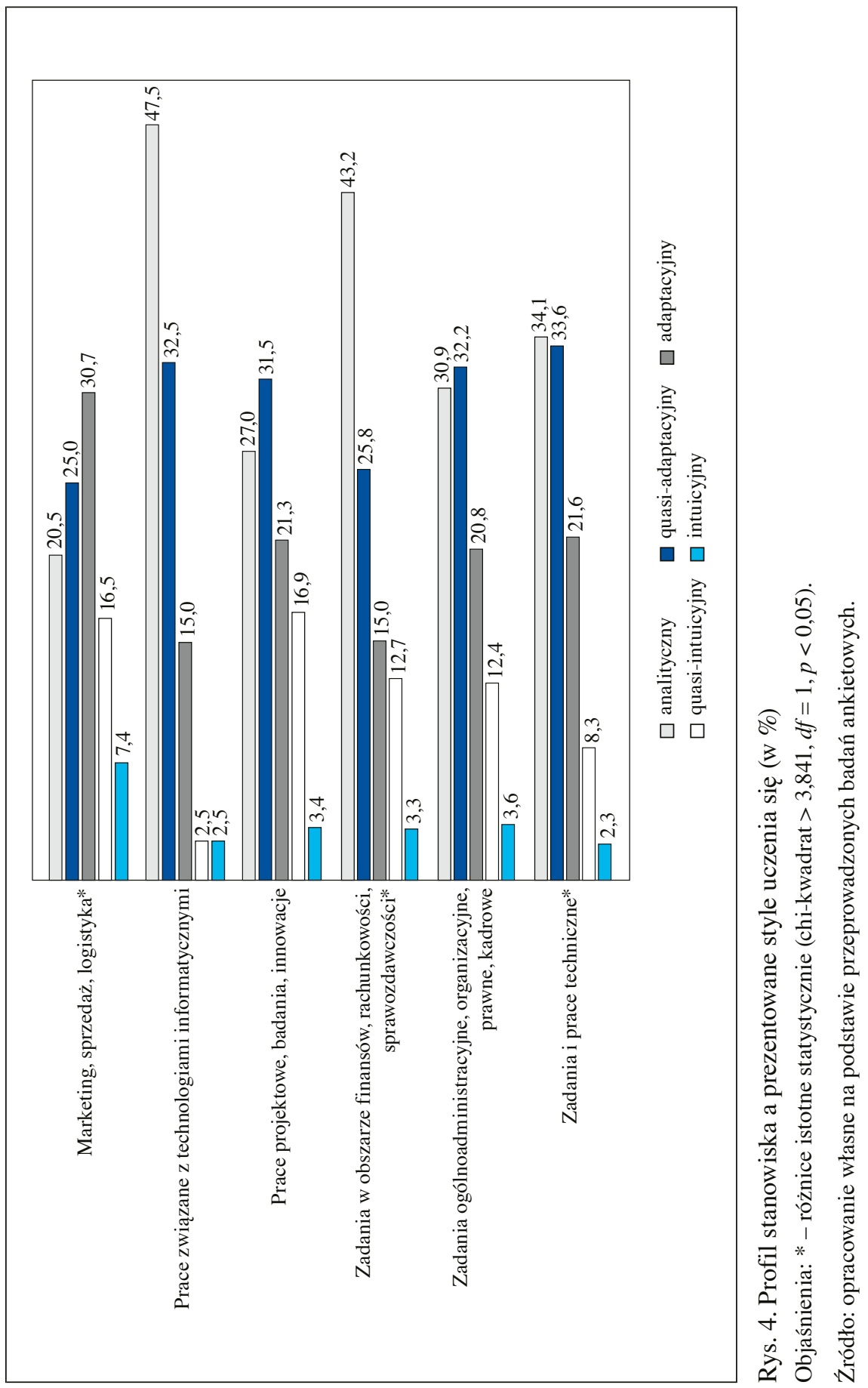


Drugi obszar tematyczny badań dotyczył stylów uczenia się respondentów. Niemal co trzeci spośród badanych prezentował styl analityczny, zaś 30,8\% respondentów styl quasi-analityczny (rys. 3). Najrzadziej występującym wśród badanych stylem uczenia się był styl intuicyjny $(3,5 \%)$.

Jedno z postawionych przez autorki pytań badawczych dotyczyło wpływu profilu stanowiska pracy na prezentowany styl uczenia się. Istotne statystycznie zależności zaobserwowano w przypadku trzech spośród sześciu rodzajów stanowisk (rys. 4).

W grupie, w której dominowały zadania i prace techniczne, co trzeci badany prezentował styl analityczny lub quasi-analityczny, zaś co piąty styl adaptacyjny. Zadania w obszarze finansów, rachunkowości, sprawozdawczości najczęściej realizowali respondenci reprezentujący styl analityczny (43\%). Badani realizujący zadania z zakresu marketingu, sprzedaży lub logistyki reprezentowali najczęściej styl adaptacyjny, a następnie quasi-analityczny i analityczny.

\section{Wnioski}

Poszukując odpowiedzi na postawione pytania badawcze, przeprowadzono badania ankietowe wśród 1365 pracowników innowacyjnych przedsiębiorstw mających siedzibę na terenie Polski. Analiza wyników badań empirycznych pozwala sformułować następujące wnioski:

1) jeśli chodzi o posiadane umiejętności, respondenci wskazywali najczęściej umiejętność organizacji czasu pracy własnej (60\% badanych). Często wskazywali także umiejętność uczenia się oraz współpracę z ludźmi w każdym wieku. Ponadto co trzeci badany deklarował posiadanie umiejętności radzenia sobie ze stresem, komunikacji interpersonalnej lub szybkiego adaptowania się do nowych warunków. Są to niewątpliwie obszary istotne na współczesnym, turbulentnym rynku pracy. Od posiadania tych kompetencji niejednokrotnie zależy możliwość utrzymania się na rynku pracy, dostosowania do wymagań pracodawcy, mobilność lub elastyczna zmiana profilu wykonywanych zadań [Raport płacowy... 2016]. Wyniki badań w tym zakresie korespondują z prezentowanymi w literaturze przedmiotu. W szczególności dotyczy to umiejętności uczenia się, która została wskazana jako jedna z najważniejszych przez pracodawców badanych w ogólnopolskim projekcie Bilans Kapitału Ludzkiego [Górniak 2014];

2) najrzadziej wskazywana przez respondentów była umiejętność współpracy z przedstawicielami innych kultur. Może to wynikać ze specyfiki polskiego rynku pracy lub analizowanych przedsiębiorstw, wciąż dość jednorodnych kulturowo. Zgodnie z obserwowanymi tendencjami i napływem, także do Polski, osób z krajów odmiennych kulturowo, będzie się to jednak stopniowo zmieniać 
i w przyszłości zapotrzebowanie na tego typu umiejętności będzie niewątpliwie wzrastać. Podobne wnioski wysnuć można z analizy wyników badań innych autorów prezentowanych w literaturze przedmiotu [Bieniek i Steinerowska 2014, Mead, Andrews i Drogosz 2011].

3) analiza wyników badań wykazała występowanie istotnych statystycznie zależności pomiędzy wykonywanymi zadaniami a umiejętnościami badanych. Specyfika stanowiska okazała się determinantą określonych kompetencji respondentów. Oznacza to, że wartości tych umiejętności w przypadku niektórych analizowanych stanowisk pracy odbiegały znacznie od wartości w przypadku pozostałych stanowisk. Przykładowo umiejętność organizacji czasu pracy własnej oraz szybkiej adaptacji do nowych warunków charakteryzuje w szczególności badanych zajmujących się pracami projektowymi i innowacyjnymi. Z kolei umiejętność komunikacji interpersonalnej istotnie częściej stanowiła mocną stronę respondentów realizujących zadania administracyjne, organizacyjne, prawne lub kadrowe. Uzyskanie odpowiedzi na postawione w tym zakresie pytanie badawcze umożliwiło tym samym realizację celu badań;

4) jeśli chodzi o style uczenia się, ponad $60 \%$ badanych prezentowało styl analityczny lub quasi-analityczny. Najrzadziej występującym wśród badanych stylem uczenia się był styl intuicyjny. Może to wynikać ze specyfiki pracy badanych, z których większość zajmowała stanowiska specjalistyczne lub wykonawcze. Zadania podejmowane przez nich wiążą się najczęściej z potrzebą skrupulatnej analizy informacji i wykonywaniem raczej systematycznych, rutynowych zadań;

5) dominujący profil stanowiska pracy okazał się czynnikiem warunkującym styl uczenia się. Istotne statystycznie różnice zaobserwowano w przypadku trzech spośród sześciu ocenianych profili stanowisk. W grupie, w której dominowały zadania i prace techniczne, co trzeci badany prezentował styl analityczny lub quasi-analityczny. Zadania w obszarze finansów lub sprawozdawczości najczęściej realizowali reprezentanci stylu analitycznego. Zadania z zakresu marketingu, sprzedaży lub logistyki realizowali respondenci, u których dominował styl adaptacyjny. Uzyskanie odpowiedzi na drugie z postawionych pytań badawczych, umożliwiło realizację celu badań.

Wyniki przeprowadzonych badań mogą zostać wykorzystane przez menedżerów oraz specjalistów HR podczas projektowania systemów zarządzania zasobami ludzkimi dostosowanych do potrzeb pracowników reprezentujących poszczególne grupy stanowisk. Warto zabiegać o poznanie mocnych stron, jak również - często z nimi powiązanych - stylów poznawczych charakteryzujących poszczególnych pracowników. Wiedza ta może być wykorzystywana przez kadrę kierowniczą m.in. podczas prowadzenia rekrutacji i selekcji, ponieważ pozwala dobierać członków zespołu w sposób bardziej świadomy. Jeśli uwzględniony 
zostanie indywidualny styl poznawczy nowego pracownika skuteczniejszy może być także proces adaptacji i wyboru mentora.

Kolejnym obszarem, w którym znajomość stylu poznawczego może mieć zastosowanie, jest podział zadań pomiędzy pracowników umożliwiający poprawę wydajności poszczególnych członków zespołu oraz usprawnienie komunikacji między nimi. Znajomość stylu uczenia się może być także przydatna przy prowadzeniu okresowej oceny pracownika [Allinson i Hayes 2012].

W literaturze podkreśla się kluczową rolę kadry kierowniczej w procesie modyfikacji stylów uczenia się pracowników organizacji oraz konieczność podnoszenia kompetencji przez menedżerów. To właśnie zdobyta przez nich wiedza i umiejętności będą bowiem przekazywane na niższe szczeble organizacji [Sitko-Lutek 2001]. Wiedza o stylach uczenia się pozwala kadrze kierowniczej na wybranie optymalnej oferty szkoleniowej dla swojego zespołu [Allinson i Hayes 2012].

Prezentowane badania nie wyczerpują wszystkich aspektów związanych ze stylem uczenia się i umiejętnościami pracowników. W przyszłości warto rozważyć pogłębione badania uwzględniające proponowany model badawczy, obejmujący obszar zarówno umiejętności, jak również stylów poznawczych charakteryzujących pracowników. W szczególności można podjąć badania, w których brane będą pod uwagę zmiany obserwowane na rynku pracy w obszarze społecznym, ekonomicznym i technologicznym czy konieczność współpracy wielu różnych pokoleń. Warto także podjąć dalsze badania nad determinantami stylów poznawczych oraz kształtowaniem umiejętności pracowników o zróżnicowanym potencjale.

\section{Literatura}

Allinson Ch., Hayes J. [2012], The Cognitive Style Index. Technical Manual and User Guide, Pearson, UK.

Antonacopoulou E.P., Fitzgerald L. [1996], Reframing Competency in Management Development, „Human Resource Management Journal”, vol. 6, nr 1, https://doi.org/ 10.1111/j.1748-8583.1996.tb00395.x.

Argyle M. [1967], The Psychology of Interpersonal Behaviour, Penguin, Harmondsworth.

Bartkowiak G. [2011], Dobrostan pracowników, poziom „zdrowia organizacji” a ich zadowolenie z pracy i zaangażowanie w realizację celów organizacji, „Prace Naukowe Uniwersytetu Ekonomicznego we Wrocławiu", nr 223.

Bieniek I., Steinerowska S. [2014], Kompetencje międzykulturowe na mapie kompetencji zawodowych menedżera, „Zeszyty Naukowe Organizacja i Zarządzanie”, z. 71.

Borkowska S. [2010], Równowaga między pracq a życiem pozazawodowym, „Acta Universitatis Lodziensis. Folia Oeconomica", nr 214.

Boyatzis R.E. [1982], The Competent Manager: A Model for Effective Performance, John Wiley and Sons, New York. 
Briscoe J.P., Hall D.T. [2006], The Interplay of Boundaryless and Protean Careers: Combinations and Implications, ,, Journal of Vocational Behavior”, vol. 69, nr 1, https://doi. org/10.1016/j.jvb.2005.09.002.

Filipowicz G. [2014], Zarzqdzanie kompetencjami. Perspektywa firmowa i osobista, Wolters Kluwer Business, Warszawa.

Juceviciene P., Lepaitte D. [2004], Competences as Derived from Acidity: The Problem of Their Level Correspondence, Kaunas University of Technology, Institute of Educational Studies, Kaunas.

Kompetencje Polaków a potrzeby polskiej gospodarki. Raport podsumowujacy IV edycje badań BKL z 2013 r. [2014], red. J. Górniak, PARP, Warszawa.

Kryńska E. [2003], Deregulacja a segmentacja rynku pracy [w:] Deregulacja polskiego rynku pracy, red. K.W. Frieske, Instytut Pracy i Spraw Socjalnych, Warszawa.

Kryńska E. [2007], Wpływ mega trendów światowych na polski rynek pracy, „Acta Universitatis Lodziensis. Folia Oeconomica", nr 207.

Leksykon zarzq̨dzania [2006], red. A. Olczak, I. Kołodziejczyk-Olczak, Wydawnictwo Wyższej Szkoły Humanistyczno-Ekonomicznej w Łodzi, Łódź.

Łaguna M., Purc E., Razmus W., Błaszyk M., Gawrońska K. [2015], Podejmowanie szkoleń a kultura i rozwój organizacyjny, „Organizacja i Kierowanie”, nr 2(167).

Matczak A. [2004], Style poznawcze [w:] Psychologia. Podręcznik akademicki, t. 2, red. J. Strelau, Gdańskie Wydawnictwo Psychologiczne, Gdańsk.

Mead R., Andrews T.G., Drogosz P. [2011], Zarzqqdzanie międzynarodowe, Wolters Kluwer Polska, Warszawa.

Mietzel G. [2003], Wprowadzenie do psychologii, Gdańskie Wydawnictwo Psychologiczne, Gdańsk.

Oleksyn T. [2006]. Zarzqdzanie kompetencjami. Teoria i praktyka, Oficyna Ekonomiczna, Kraków.

Pissarides Ch.A. [2012], Teoria bezrobocia $w$ stanie równowagi, PWE, Warszawa.

Polskie firmy wobec globalizacji. Luka kompetencyjna [2007], red. A. Sitko-Lutek, Wydawnictwo Naukowe PWN, Warszawa.

Prien E.P. [1977], The Function of Job Analysis in Content Validation, „Personnel Psychology", vol. 30, nr 2, https://doi.org/10.1111/j.1744-6570.1977.tb02086.x.

Rakowska A. [2007], Kompetencje menedżerskie kadry kierowniczej we współczesnych organizacjach, Wydawnictwo Uniwersytetu Marii Curie-Skłodowskiej, Lublin.

Rakowska A., Sitko-Lutek A. [2000], Doskonalenie kompetencji menedżerskich, PWN, Warszawa.

Raport płacowy 2016. Trendy na rynku pracy [2016], HAYS, Akademia Leona Koźmińskiego, Warszawa.

Riding R., Rayner S. [1998], Cognitive Styles and Learning Strategies, David Fulton Publisher, London.

Shavelson R.J. [2010], On the Measurement of Competency, „Empirical Research in Vocational Education and Training", vol. 2, nr 1.

Sikorski C. [2008], Typy i dylematy kariery zawodowej, „Organizacja i Zarządzanie”, nr 1.

Sitko-Lutek A. [2001], Doskonalenie kompetencji polskich menedżerów w oparciu o znajomość stylów uczenia się i kultury organizacyjnej [w:] Zarzq̨anie zasobami informacji w przedsiębiorstwie. Ku przedsiębiorstwu przyszłości, red. R. Borowiecki, M. Kwieciński, Wydawnictwo Naukowo-Techniczne, Warszawa. 
Sztanderska U., Wojciechowski W. [2008], Czego (nie) uczq polskie szkoły? System edukacji a potrzeby rynku pracy w Polsce, Fundacja Forum Obywatelskiego Rozwoju, Fundacja im. Friedricha Eberta, Warszawa.

Verbruggen M. [2010], Career Counseling in the New Career Era, „Review of Business and Economics", vol. LV, nr 1.

Wernerfelt B. [1984], A Resource-based View of the Firm, „Strategic Management Journal", vol. 5, nr 1, https://doi.org/10.1002/smj.4250050207.

\section{Learning Styles and Employee Skills in the Context of Selected Segments of the Labour Market}

(Abstract)

The paper examines learning styles and employee skills at innovative companies. These were evaluated in the context of selected segments of the labour market. The modern labour market may be analyzed using numerous criteria. The focus here was on the division of positions in organizations. The authors sought to determine whether positions occupied by respondents affected their learning styles and skills. The results of the study can be applied by HR managers and specialists in designing human resource management systems that can be adjusted to the needs of employees representing particular position types.

The empirical study was conducted by means of a diagnostic survey based on a questionnaire. 1365 employees of innovative companies located in Poland replied and the questionnaires were analyzed with statistical methods. The results enabled recommendations for HR managers and specialists to be formulated. The recommendations pertain to the management of teams in modern enterprises.

Keywords: learning styles, employee skills, labour market segment, competencies. 